\title{
FAKTOR-FAKTOR YANG MEMPENGARUHI PENGELUARAN RUMAH TANGGA PEKERJA WANITA YANG BEKERJA DI INDUSTRI LAUNDRY RUMAH TANGGA DI KECAMATAN DENPASAR SELATAN
}

\author{
Wiji Rosiana ${ }^{1}$ \\ Ida Ayu Nyoman Saskara \\ ${ }^{1,2}$ Fakultas Ekonomi dan Bisnis Universitas Udayana (Unud), Bali, Indonesia \\ Email: rosianawiji@yahoo.com
}

\begin{abstract}
ABSTRAK
Pertumbuhan ekonomi yang pesat mengakibatkan bermunculan industri kecil, menengah, maupun besar. Salah satu industri yang berkembang pesat adalah industri laundry rumah tangga, yang mana sebagian besar pekerjanya adalah wanita. Tujuan dari penelitian ini adalah: 1) Untuk menganalisis pengaruh tingkat pendidikan, upah pekerja, pendapatan suami, umur, jumlah tanggungan keluarga dan jam kerja secara langsung terhadap pengeluaran rumah tangga; 2) Untuk menganalisis pengaruh tingkat pendidikan, upah pekerja, pendapatan suami, umur dan jumlah tanggungan keluarga terhadap pengeluaran rumah tangga melalui jam kerja. Metode pengumpulan data yang digunakan adalah wawancara dan kuisioner, dengan jumlah responden sebanyak 87 orang. Alat analisis yang digunakan adalah analisis deskriptif dan analisis jalur. Hasil penelitian menunjukkan tingkat pendidikan, upah pekerja dan pendapatan suami berpengaruh positif signifikan terhadap jam kerja pekerja wanita. Umur berpengaruh negatif signifikan terhadap jam kerja pekerja wanita. Jumlah tanggungan keluarga berpengaruh positif tidak signifikan terhadap jam kerja pekerja wanita. Upah pekerja, pendapatan suami, jumlah tanggungan keluarga dan jam kerja berpengaruh positif signifikan terhadap pengeluaran rumah tangga pekerja wanita. Tingkat pendidikan dan umur berpengaruh negatif tidak signifikan terhadap pengeluaran rumah tangga pekerja wanita. Jam kerja memediasi pengaruh Tingkat pendidikan, upah pekerja, pendapatan suami dan umur terhadap pengeluaran rumah tangga pekerja wanita. Sedangkan jam kerja tidak memediasi jumlah tanggungan keluarga terhadap pengeluaran rumah tangga pekerja wanita yang bekerja di industri laundry rumah tangga di Kecamatan Denpasar Selatan.
\end{abstract}

Kata kunci: pekerja wanita, pengeluaran rumah tangga, jam kerja.

\begin{abstract}
Rapid economic growth has resulted in the emergence of small, medium, and large industries. One of the fastest growing industries is the household laundry industry, where most of the workers are women. The purpose of this research are: 1) To analyze the effect of education level, worker's wage, husband's income, age, number of family dependent and working hours directly to household expenditure; 2) To analyze the effect of education level, worker's wage, husband's income, age and amount of family dependent on household expenditure through working hours. Data collection methods used were interviews and questionnaires, with a total of 87 respondents. The analytical tool used is descriptive analysis and path analysis. The results showed that the level of education, worker's wage and husband's income had a positive significant impact on the working hours of female workers. Age negatively significantly affects the working hours of female workers. The number of family dependents has a positive insignificant effect on the working hours of female workers. Worker's wage, husband's income, the number of family dependents and working hours have a positive significant impact on the expenditure of female workers' households. The level of education and age has a negative insignificant effect on the expenditure of female workers' households. Working hours mediate the influence of education level, the influence of the wage of the worker, the husband's income and age on the expenditure of the female worker's household. While working hours do not mediate the number of family dependents on household expenditure of female workers working in the household laundry industry in South Denpasar District.
\end{abstract}

Keywords: woman worker, household expenses, working hours. 
Wiji Rosiana, dan Ida Ayu Nyoman Saskara. Faktor-faktor yang menghambat..

\section{PENDAHULUAN}

Pertumbuhan ekonomi yang pesat mengakibatkan bermunculan industri kecil, menengah, maupun besar untuk memenuhi kebutuhan yang terus meningkat. Salah satu industri yang berkembang pesat adalah industri laundry rumah tangga, yang mana sebagian besar pekerjanya adalah wanita. Dewasa ini perempuan tidak hanya berperan sebagai ibu rumah tangga. Tuntutan sosial dan ekonomi rumah tangga mendorong perempuan mencari nafkah untuk menambah penghasilan keluarga. Meningkatnya peluang bagi wanita untuk masuk ke dalam pasar kerja disebabkan oleh tersedianya lapangan kerja yang mudah dimasuki oleh wanita seperti usaha buka warung, pembantu rumah tangga, industri kecil rumah tangga dan usaha dagang yang dimana termasuk usaha dagang banten yang terdapat di Provinsi Bali (Saskara dan Marhaeni, 2017). Industri kecil yang dilakukan di rumah banyak menyerap tenga kerja wanita (Scolten, 1987). Kemajuan suatu daerah dapat dilihat dari perkembangan kegiatan industri didaerah tersebut. Perkembangan industri dapat membantu menyerap tenaga kerja. Penyediaan lapangan pekerjaan yang secara otomatis akan sangat berpengaruh terhadap tingkat pendapatan perkapita masyarakatnya (Kurniawan, 2016).

Provinsi Bali sendiri banyak terdapat usaha-usaha kecil seperti industri kerajinan, industri pengolahan makanan, industri pakaian, industri laundry rumah tangga dan lain sebagainya. Usaha laundry rumah tangga berkembang dengan sangat pesat. Dengan modal yang tidak terlalu besar, membuat usaha laundry berkembang pesat khususnya di Kota Denpasar. 
E-Jurnal Ekonomi dan Bisnis Universitas Udayana 7.11 (2018): 2357-2388

Tabel 1. Jumlah Usaha Laundry di Kota Denpasar per Kecamatan

Tahun 2016

\begin{tabular}{|l|c|c|}
\hline \multicolumn{1}{|c|}{ Kecamatan } & $\begin{array}{c}\text { Jumlah usaha } \\
\text { Laundry }\end{array}$ & $\begin{array}{c}\text { Persentase } \\
\%\end{array}$ \\
\hline Denpasar Utara & 29 & 9,45 \\
\hline Denpasar Barat & 107 & 34,85 \\
\hline Denpasar Selatan & 145 & 47,23 \\
\hline Denpasar Timur & 26 & 8,47 \\
\hline Jumlah & 307 & 100 \\
\hline
\end{tabular}

Sumber : Dinas Koperasi dan UMKM Kota Denpasar

Tabel diatas menunjukkan bahwa jumlah usaha laundry di Kecamatan Denpasar Selatan yang paling tinggi yaitu sebanyak 145 unit dengan persentase sebesar 47,23 persen, kemudian Kecamatan Denpasar Barat yaitu sebanyak 107 unit dengan pesentase sebesar 34,85 persen, Kecamatan Denpasar Utara sebanyak 29 unit dengan persentase sebesar 9,45 persen dan yang terakhir Kecamatan Denpasar Timur sebanyak 26 unit dengan persentase sebesar 8,47 persen. Usaha laundry rumah tangga banyak menyerap tenaga kerja wanita, karena wanita dianggap lebih terampil dalam melalukan pekerjaan mencuci dibandingkan dengan laki-laki. Persaingan laundry rumah tangga saat ini cukup ketat, dapat dilihat dari perkembangan usaha laundry rumah tangga yang semakin menjamur, walaupun usaha laundry profesional semakin banyak tersebar di wilayah Kota Denpasar. Usaha laundry rumah tangga harus meningkatkan kualitas bekerja dari karyawannya sehingga mendapatkan hasil yang sesuai dengan target yang akan dicapai.

Usaha laundry bisa dijadikan pekerjaan sampingan bagi ibu rumah tangga dan sekaligus sebagai pekerjaan utama bagi pengusaha, karena selain cara usahanya yang relatif mudah dan modal usaha tidak terlalu besar, tetapi 
Wiji Rosiana, dan Ida Ayu Nyoman Saskara. Faktor-faktor yang menghambat..

keuntungannya cukup besar. Provinsi Bali khususnya kerap sekali terjadi diskriminasi antara pria dan wanita. Wanita sering sekali mendapatkan posisi yang kurang menguntungkan, karena didalam pekerjaannya, pendapatan pria lebih besar dibandingkan pendapatan wanita sehingga pria bisa memberi kontribusi terhadap keluarganya untuk kebutuhan pengeluaran rumah tangga (Anastia, 2014). Menurut Espinal (1997), wanita yang terlibat dalam pekerjaan mencari nafkah akan mempengaruhi pola kerja rumah tangga. Keterlibatan perempuan dalam dunia kerja guna memberikan pemerataan terhadap proses pembangunan merupakan suatu keharusan, walaupun masih terjadi diskriminasi. Adanya gerakan-gerakan serta kajian-kajian perempuan, memberikan kesempatan bagi perempuan untuk bisa tampil di dunia yang secara tradisional dianggap dunia pria (Saskara dkk, 2012).

Waktu untuk bekerja antara pria dan wanita berbeda, hal ini disebabkan wanita memiliki peran ganda yaitu mengurus keluarga dan bekerja. Menurut Ware (1981), terdapat dua alasan penting yang perlu dipahami ketika membicarakan latar belakang keterlibatan wanita dalam angkatan kerja, pertama adalah keharusan, karena kondisi ekonomi rumah tangga yang rendah, sehingga wanita harus bekerja untuk meningkatkan pendapatan rumah tangga menjadi penting. Seperti yang dijelaskan oleh Saskara dan Marhaeni (2017), bahwa keterlibatan perempuan dalam pasar kerja selain untuk membantu meningkatkan pendapatan rumah tangga juga untuk aktualisasi diri, kedua adalah memilih untuk bekerja, karena kondisi sosial ekonomi pada level menengah ke atas. Wanita berkegiatan atau berusaha memperoleh penghasilan (bekerja) bisa disebabkan oleh beberapa 
hal, antara lain adanya kemauan wanita untuk mandiri secara ekonomi yaitu berusaha membiayai kebutuhan hidupnya sendiri dan mungkin juga kebutuhan hidup dari orang-orang yang menjadi tanggungannya. Selain itu, adanya kebutuhan untuk menambah atau memperkuat penghasilan keluarga atau rumah tangganya (Pratomo, 2017).

Menurut Larsson dkk (1987:74), keputusan untuk bekerja merupakan suatu hal dimana seseorang harus mampu membagi waktunya, salah satu cara untuk memanfaatkan waktu yang tersedia yaitu dengan melakukan aktifitas di waktu senggang. Selain itu juga cara yang dilakukan orang untuk memanfaatkan waktunya adalah dengan cara bekerja. Indikator tingkat kesejahteraan suatu rumah tangga dipengaruhi oleh individu dan status sosial ekonomi dalam rumah tangga tersebut (Chandrasekhar dkk, 2014), karena alasan itulah setiap rumah tangga berusaha menutupi pengeluaran rumah tangganya dengan bekerja.

Perkembangan zaman dan pembangunan di Kota Denpasar, mengakibatkan penduduk diwilayah Kota Denpasar memliki pekerjaan yang bervariasi. Pekerjaan di sektor informal menjadi salah satu mata pencaharian masyarakat yang memiliki potensi dalam memberikan konstribusi terhadap pendapatan keluarga (Adi, 2013). Sektor informal penting bagi masyarakat yang tingkat ekonominya kurang, sehingga sektor ini dapat dipakai sebagai sumber pendapatan dan memaksimalkan keuntungan dengan bekerja pada kegiatan di sektor informal (Neves dan Du Toit, 2012). 
Tabel 2. Jumlah Rumah Tangga, Rata-Rata Penduduk dan Kepadatan Penduduk di Kota Denpasar Tahun 2016

\begin{tabular}{|l|c|c|c|c|}
\hline \multicolumn{1}{|c|}{ Kecamatan } & $\begin{array}{c}\text { Jumlah } \\
\text { Rumah } \\
\text { Tangga }\end{array}$ & $\begin{array}{c}\text { Rata-Rata } \\
\text { Penduduk Per } \\
\text { Rumah } \\
\text { Tangga } \\
\text { (orang) }\end{array}$ & $\begin{array}{c}\text { Jumlah } \\
\text { penduduk per } \\
\text { Desa (orang) }\end{array}$ & $\begin{array}{c}\text { Kepadatan } \\
\text { Penduduk } \\
\left(\text { Per Km }{ }^{2} \text { ) }\right.\end{array}$ \\
\hline Denpasar Selatan & 88.966 & 3 & 286.060 & 5.722 \\
\hline Denpasar Timur & 44.855 & 3 & 153.480 & 6.879 \\
\hline Denpasar Barat & 83.027 & 3 & 259.790 & 10.798 \\
\hline Denpasar Utara & 58.918 & 3 & 197.970 & 6.301 \\
\hline Kota Denpasar & 275.766 & 3 & 897.300 & 29.700 \\
\hline
\end{tabular}

Sumber : BPS Kota Denpasar

Tabel diatas menunjukan jumlah penduduk di Kecamatan Denpasar Selatan yang paling besar yaitu 286.060 orang per desa, dengan jumlah rumah tangga yaitu 88.966 dan rata-rata penduduk per rumah tangga adalah 3 orang, sedangkan jumlah penduduk di Kecamatan Denpasar Timur yang yang paling sedikit yaitu 153.480 orang per desa, dengan jumlah rumah tangga yaitu 44.855 dan rata-rata penduduk per rumah tangga adalah 3 orang.

Tabel 3. Jumlah Usaha Laundry dan karyawan di Kecamatan Denpasar Selatan Tahun 2016

\begin{tabular}{|c|l|c|c|}
\hline No & Nama Desa & $\begin{array}{c}\text { Jumlah Usaha } \\
\text { Laundry }\end{array}$ & $\begin{array}{c}\text { Jumlah Karyawan } \\
\text { (orang) }\end{array}$ \\
\hline 1 & Panjer & 12 & 53 \\
\hline 2 & Pemogan & 20 & 92 \\
\hline 3 & Renon & 11 & 51 \\
\hline 4 & Sanur & 13 & 59 \\
\hline 5 & Sanur kaja & 13 & 60 \\
\hline 6 & Sanur kauh & 23 & 107 \\
\hline 7 & Sesetan & 25 & 116 \\
\hline 8 & Sidakarya & 28 & 126 \\
\hline 9 & Serangan & 0 & 0 \\
\hline 10 & Pedungan & 0 & 664 \\
\hline \multicolumn{2}{|c|}{ Jumlah } & 145 & 0 \\
\hline
\end{tabular}

Sumber: Dinas Koperasi dan UMKM Kota Denpasar, 2016 
Tabel diatas menjelaskan tentang jumlah laundry dan jumlah karyawan di Kecamatan Denpasar Selatan. Dari total 10 desa yang ada, Desa Sidakarya memiliki jumlah usaha laundry paling banyak yaitu 28 unit dan jumlah karyawannya yaitu 126 orang, sedangkan Desa Renon memiliki jumlah usaha laundry paling sedikit yaitu 11 unit dan jumlah karyawannya yaitu 51 orang. Menurut Handoko (2009) didalam penelitiannya menyatakan bahwa, aktivitas dan kesibukan kerja yang banyak dijumpai di wilayah perkotaan seringkali menyebabkan warganya yang umumnya berprofesi sebagai karyawan maupun pelajar yang tingga di tempat kos sering tidak punya cukup waktu untuk melakukan aktivitas harian seperti memasak atau mencuci. Masa liburan akhir pekan dinilai lebih layak digunakan untuk bersantai bersama keluarga daripada untuk mencuci pakaian kotor, dengan alasan praktis dan biaya yang cukup murah, keberadaan jasa laundry semakin banyak dijumpai.

Tingkat pendidikan juga berpengaruh penting terhadap tenaga kerja. Pendidikan sebagai penyiapan tenaga kerja diartikan sebagai kegiatan membimbing peserta didik sehingga memiliki bekal dasar untuk bekerja. Pembekalan dasar berupa pembentukan sikap, perilaku, pengetahuan, dan ketrampilan. Diharapkan dengan tingkat pendidikan yang tinggi, akan terlahir tenaga kerja yang mempunyai pengetahuan dan ketrampilan yang cukup untuk bisa bersaing di dunia kerja, dengan demikian tingkat pendidikan sangat berpengaruh penting dalam pertumbuhan ekonomi di suatu daerah. Pendidikan yang tinggi dapat meningkatkan kemampuan sumber daya manusia, pembangunan sumber daya manusia dalam suatu negara akan menentukan karakter dari 
pembangunan ekonomi dan sosial, karena manusia mempunyai perilaku aktif yang dapat mengakumulasi modal, mengeksploitasi berbagai sumber daya serta menjelaskan berbagai kegiatan ekonomi, sosial dan politik yang sangat penting bagi pertumbuhan sosial (Erwin dkk, 2012).

Jumlah tanggungan keluarga akan berpengaruh terhadap pengeluaran konsumsi rumah tangga. Kewajiban suami sebagai kepala rumah tangga adalah untuk memenuhi kebutuhan rumah tangga, semakin banyak tanggungan akan semakin banyak pula pengeluaran konsumsi rumah tangga. Jika pendapatan suami belum mencukupi untuk memenuhi kebutuhan rumah tangga, di sinilah peran ibu rumah tangga yang ingin membantu memenuhi kebutuhan rumah tangga, sehingga memutuskan untuk bekerja disamping tugasnya sebagai ibu rumah tangga. Keluarga dengan dua sumber pendapatan (suami dan istri yang bekerja) dirasa lebih dapat meningkatkan kualitas standar hidupnya dan sangat erat hubungannya dengan pola konsumsi (Kaufman dan Hotchkiss, 2000). Kurangnya pendapatan keluarga adalah faktor yang menyebabkan perempuan bekerja, selain itu juga karena pendapatan suami yang diperoleh terkadang tidak cukup untuk memenuhi kebutuhan keluarga (Paula, 2002). Sebuah keluarga seharusnya memperhatikan jumlah anak, karena hal tersebut dapat mempengaruhi pendapatan keluarga (Rahayu dan Tisnawati, 2014).

Faktor lain yang mendorong ibu rumah tangga untuk bekerja adalah umur. Jika seorang wanita sudah berusia 15 tahun keatas, akan bertambah juga tanggung jawab yang harus diterima dan harus mencari pekerjaan. Jika usia kerja atau usia 
produktif semakin tinggi yaitu antara 15-64 tahun, maka akan bertambah pula tingkat konsumsinya (Weni, 2016).

\section{Hubungan Upah Pekerja Terhadap Pengeluaran Rumah Tangga}

Pendapatan atau upah bagi para pekerja memiliki dua manfaat yaitu: Pertama, sebagai imbalan upah yaitu hak dari pekerja terhadap tenaga atau pikiran yang telah dikeluarkan. Kedua, sebagai perangsang produktivitas yaitu upah dapat meningkatkan motivasi pekerja untuk belajar lebih giat (Dwi dan Desi, 2013). Menurut Case dan Fir (2002) didalam penelitiannya, Keynes mengemukakan 2 point yaitu:

1) Keynes mengemukakan bahwa konsumsi adalah fungsi positif dari pendapatan, semakin banyak pendapatan, semakin banyak konsumsi yang cenderung dilakukan. Orang kaya umumnya mengkonsumsi lebih banyak daripada orang miskin.

2) Keynes mengemukakan bahwa rumah tangga yang berpendapatan tinggi mengkonsumsi bagian yang lebih sedikit dari pendapatan mereka dibandingkan dengan rumah tangga yang berpendapatan rendah.

\section{Hubungan Pendapatan Suami Terhadap Pengeluaran Rumah Tangga.}

Dalam penelitian Nurul (2006), pendapatan suami berperan sangat penting untuk memenuhi kebutuhan keluarga. Pendapatan suami berpengaruh negatif atau positif terhadap pendapatan pedagang. Tergantung besar kecilnya pendapatan suami, pendidikan suami yang tinggi akan memperoleh pendapatan yang tinggi. Jika pendapatan seseorang semakin besar maka akan semakin besar pula 
Wiji Rosiana, dan Ida Ayu Nyoman Saskara. Faktor-faktor yang menghambat..

pengeluaran konsumsi seseorang. Pendapatan yang besar membuat seseorang menjadi lebih konsumtif dan menuntut kualitas yang lebih baik (Hyman, 2012).

\section{Hubungan Tingkat Pendidikan Terhadap Pengeluaran Rumah Tangga.}

Menurut Rahardja dan Manurung (2005), semakin tinggi pendidikan seseorang pengeluaran konsumsinya juga akan semakin tinggi, sehingga mempengaruhi pola konsumsi dan hubungannya positif. Pada saat seseorang atau keluarga memiliki pendidikan yang tinggi, kebutuhan hidupnya juga akan semakin bertambah. Kondisi ini disebabkan karena yang harus mereka penuhi bukan hanya sekedar kebutuhan untuk makan dan minum, tetapi juga kebutuhan informasi, pergaulan di masyarakat baik, dan kebutuhan akan pengakuan orang lain terhadap keberadaannya. Kami menemukan bahwa, rata-rata, laba bersih ibu rumah tangga memberikan kontribusi terhadap total pendapatan keluarga secara signifkan, diharapkan sebagai pendapatan sekunder bersih tergantung pada tingkat pendapatan dan pendidikan (Aguirre, 2006).

\section{Hubungan Umur Terhadap Pengeluaran Rumah Tangga.}

Menurut Kotakis, 2014 (dalam Rosediana, 2016), umur mempengaruhi konsumsi karena adanya perbedaan preferensi antara individu yang berusia muda dan individu yang berusia tua. Penduduk yang berusia tua akan lebih banyak menggunakan pendapatan yang diperoleh untuk biaya kesehatan mereka dibanding kelompok usia yang lain. 


\section{Hubungan Jumlah Tanggungan Keluarga Terhadap Pengeluaran Rumah Tangga.}

Hasil Survei Biaya Hidup (SBH) tahun 1989 membuktikan bahwa semakin besar jumlah anggota keluarga semakin besar proporsi pengeluaran keluarga untuk makan dari pada untuk bukan makanan, artinya semakin kecil jumlah anggota keluarga, semakin kecil pula bagian pendapatan untuk kebutuhan makanan (Sumarwan, 1993). Keluarga dengan jumlah anggota sedikit relatif lebih sejahtera dibandingkan dengan keluarga yang mempunyai jumlah anggota yang banyak.

\section{Hubungan Jam Kerja Terhadap Pengeluaran Rumah Tangga.}

Menurut Putri dan Evi (2012), bahwa semakin besar pengeluaran rumah tangga per bulan akan memotivasi pekerja untuk meluangkan lebih banyak waktu di pasar kerja. Peningkatan curahan jam kerja ini diharapkan dapat menutupi pengeluaran rumah tangga yang semakin tinggi, ada hubungan positif dan signifikan antara jam kerja terhadap pengeluaran rumah tangga perempuan menikah.

\section{Rumusan Masalah}

Berdasarkan latar belakang yang telah diuraikan adapun beberapa rumusan masalah dalam penelitian ini sebagai berikut:

1. Bagaimana pengaruh tingkat pendidikan, upah pekerja, pendapatan suami, umur, dan jumlah tanggungan keluarga secara langsung terhadap jam kerja wanita yang bekerja di industri laundry rumah tangga di Kecamatan Denpasar Selatan? 
Wiji Rosiana, dan Ida Ayu Nyoman Saskara. Faktor-faktor yang menghambat..

2. Bagaimana pengaruh tingkat pendidikan, upah pekerja, pendapatan suami, umur, jumlah tanggungan keluarga, dan jam kerja secara langsung terhadap pengeluaran rumah tangga pekerja wanita yang bekerja di industri laundry rumah tangga di Kecamatan Denpasar Selatan?

3. Apakah tingkat pendidikan, upah pekerja, pendapatan suami, umur dan jumlah tanggungan keluarga berpengaruh terhadap pengeluaran rumah tangga melalui jam kerja wanita yang bekerja di industri laundry rumah tangga di Kecamatan Denpasar Selatan?

\section{Tujuan Penelitian}

1. Untuk menganalisis pengaruh tingkat pendidikan, upah pekerja, pendapatan suami, umur dan jumlah tanggungan keluarga secara langsung terhadap jam kerja wanita yang bekerja di industri laundry rumah tangga di Kecamatan Denpasar Selatan.

2. Untuk menganalisis pengaruh tingkat pendidikan, upah pekerja, pendapatan suami, umur, jumlah tanggungan keluarga dan jam kerja secara langsung terhadap pengeluaran rumah tangga pekerja wanita yang bekerja di industri laundry rumah tangga di Kecamatan Denpasar Selatan.

3. Untuk menganalisis peran jam kerja dalam memediasi pengaruh tingkat pendidikan, upah pekerja, pendapatan suami, umur dan jumlah tanggungan keluarga terhadap pengeluaran rumah tangga pekerja wanita yang bekerja di industry laundry rumah tangga di Kecamatan Denpasar Selatan. 


\section{METODE PENELITIAN}

Metode penelitian yang digunakan dalam penelitian ini adalah kuantitatif, menggunakan data primer yang diperoleh dari responden menggunakan kuisioner. Populasi dalam penelitian ini sebanyak 664 orang dari 145 perusahaan. Dengan menggunakan rumus slovin, diperoleh sampel sebanyak 87 responden. Variabel terikat dalam penelitian ini adalah pengeluaran rumah tangga. Variabel bebas dalam penelitian ini adalah tingkat pendidikan, upah pekerja, pendapatan suami, umur dan jumlah tanggungan keluarga, sedangkan variabel intervening dalam penelitian ini adalah jam kerja. Definisi operasional dalam penelitian ini adalah:

a. Tingkat Pendidikan $\left(\mathrm{X}_{1}\right)$

Tingkat pendidikan yang dimaksud adalah jumlah tahun lamanya responden menamatkan pendidikan formal (tahun).

b. Upah Pekerja $\left(\mathrm{X}_{2}\right)$

Upah pekerja yang dimaksud adalah rata-rata gaji 6 bulan terakhir dari responden yang didapat untuk memenuhi kebutuhan rumah tangga (dalam $\mathrm{Rp})$.

c. Pendapatan Suami $\left(\mathrm{X}_{3}\right)$

Pendapatan suami yang dimaksud adalah rata-rata gaji 6 bulan terakhir dari suami yang digunakan untuk menafkahi keluarga dan untuk memenuhi kebutuhan rumah tangga termasuk pendidikan anak (dalam Rp).

d. $\operatorname{Umur}\left(\mathrm{X}_{4}\right)$

Umur yang dimaksud adalah umur dari responden yang dihitung berdasarkan ulang tahun terakhir (tahun). 
Wiji Rosiana, dan Ida Ayu Nyoman Saskara. Faktor-faktor yang menghambat..

e. Jumlah Tanggungan Keluarga $\left(\mathrm{X}_{5}\right)$

Jumlah tanggungan keluarga yang dimaksud adalah jumlah anak dan anggota keluarga lain yang seluruh biaya hidupnya menjadi tanggung jawab responden yang diukur dengan satuan jumlah orang.

f. Jam Kerja $\left(\mathrm{Y}_{1}\right)$

Jam kerja yang dimaksud adalah lamanya waktu yang dicurahkan untuk melakukan pekerjaan selama satu minggu dengan minimal 6 hari kerja yang diukur dalam satuan jam.

g. Pengeluaran Rumah Tangga $\left(\mathrm{Y}_{2}\right)$

Pengeluaran rumah tangga yang dimaksud adalah rata-rata biaya yang dikeluarkan untuk kebutuhan rumah tangga dalam 6 bulan terakhir yang diukur dalam satuan rupiah $(\mathrm{Rp})$.

\section{TEKNIK ANALISIS DATA}

\section{Teknik Analisis Jalur (Path Analysis)}

Analisis jalur adalah alat untuk mengetahui pengaruh langsung dan pengaruh tidak langsung dari suatu variabel, dimana beberapa variabel dianggap sebagai penyebab dari variabel lainnya. Pada analisis jalur terdapat suatu variabel yang dapat berperan ganda, dimana pada satu sisi suatu variabel bisa sebagai variabel independen dalam suatu hubungan namun menjadi variabel dependen pada hubungan lain mengingat adanya hubungan kausal yang berjenjang (Suyana, 2010). 


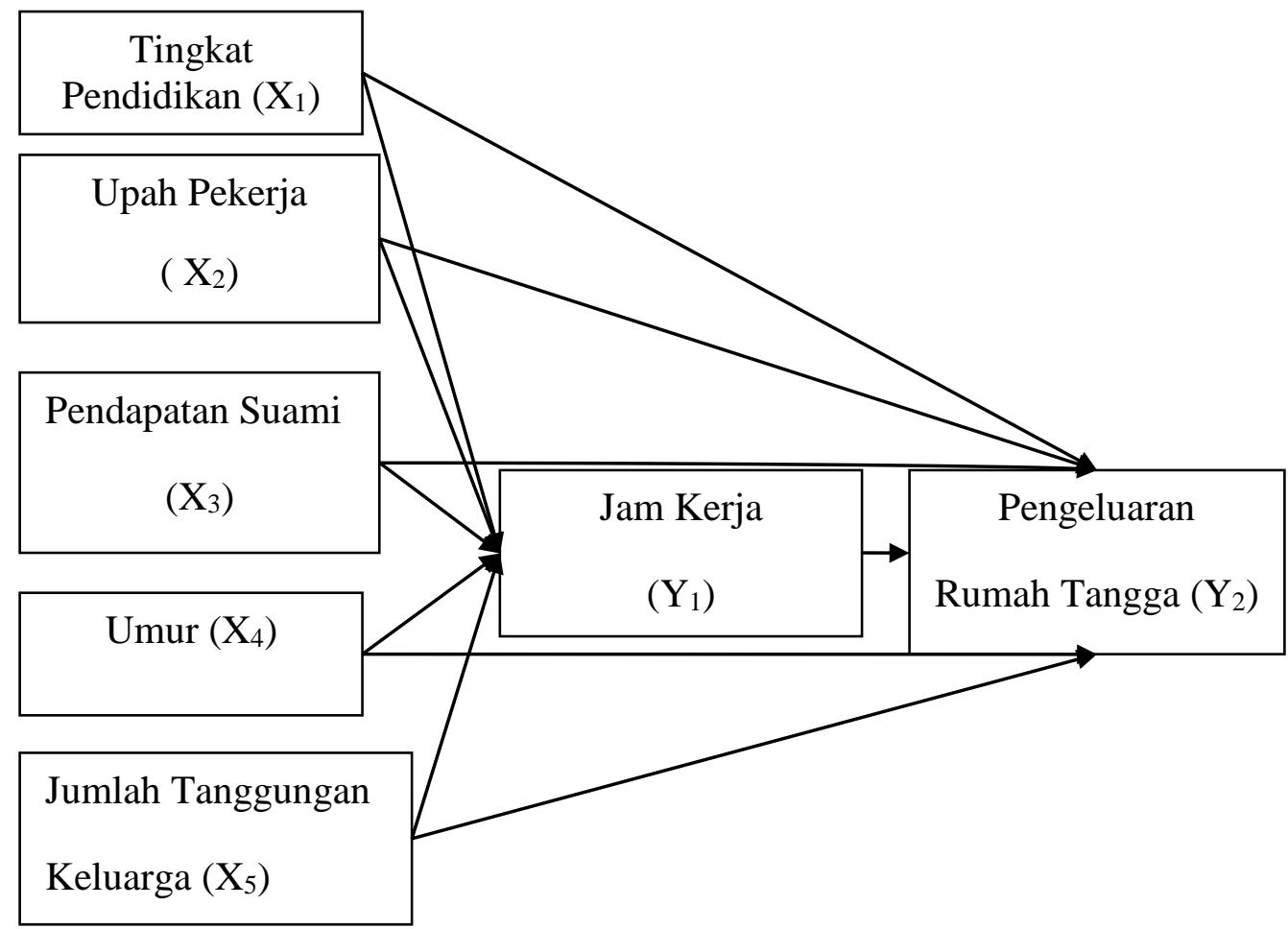

Gambar 1

Model Analisis Jalur (Path Analysis)

Persamaan struktural analisis jalur:

$Y_{1}=\beta_{1} X_{1}+\beta_{2} X_{2}+\beta_{3} X_{3}+\beta_{4} X_{4}+\beta_{5} X_{5}+\mu$

$Y_{2}=\beta_{6} X_{1}+\beta_{7} X_{2}+\beta_{8} X_{3}+\beta_{9} X_{4}+\beta_{10} X_{5}+\beta_{11} Y_{2}+\mu$

Keterangan:

$\mathrm{Y}_{1}=$ Jam Kerja

$\mathrm{Y}_{2}=$ Pengeluaran Rumah Tangga

$\mathrm{X}_{1}=$ Tingkat Pendidikan

$\mathrm{X}_{2}=$ Upah Pekerja

$\mathrm{X}_{3}=$ Pendapatan Suami

$\mathrm{X}_{4}=$ Umur

$\mathrm{X}_{5}=$ jumlah Tanggungan Keluarga 
Wiji Rosiana, dan Ida Ayu Nyoman Saskara. Faktor-faktor yang menghambat..

\section{HASIL PENELITIAN}

\section{Evaluasi Terhadap Pemenuhan Analisis Jalur}

Pemeriksaan terhadap asumsi yang melandasi analisis jalur perlu dilakukan agar hasilnya memuaskan. Asumsi yang melandasi analisis jalur adalah sebagai berikut

Tabel 4. Hubungan Linier AntarVariabel Penelitian

\begin{tabular}{|c|c|c|c|}
\hline Hubungan Variabel & R-Square & F & Sig. \\
\hline X1 -> Y1 & 0,472 & 75,819 & 0,000 \\
\hline X2 -> Y1 & 0,764 & 274,753 & 0,000 \\
\hline X3 -> Y1 & 0,741 & 242,778 & 0,000 \\
\hline X4 -> Y1 & 0,163 & 16,605 & 0,000 \\
\hline X5 -> Y1 & 0,218 & 33,262 & 0,000 \\
\hline X1 -> Y2 & 0,390 & 54,248 & 0,000 \\
\hline X2 -> Y2 & 0,838 & 438,124 & 0,000 \\
\hline X3 -> Y2 & 0,807 & 355,527 & 0,000 \\
\hline X4 -> Y2 & 0,256 & 29,262 & 0,000 \\
\hline X5 -> Y2 & 0,436 & 65,700 & 0,000 \\
\hline Y1 -> Y2 & 0,764 & 274,726 & 0,000 \\
\hline
\end{tabular}

Sumber:data diolah, 2017

Berdasarkan tabel 4 dapat dilihat bahwa tidak ada variabel yang tidak berhubungan secara linear antar satu dengan yang lainnya. Hubungan antar variabel menunjukkan hubungan yang linear dilihat dari nilai signifikansi yang kurang dari 0,05 . Hubungan yang paling linear adalah antara X2 $\rightarrow$ Y2, yaitu ditunjukkan oleh F-Hitung paling besar, yaitu sebesar 438,124.

\section{Evaluasi Terhadap Validitas Model}

Validitas model struktural dapat dilihat dari nilai R2 dari variabel dependen. Nilai R2 variabel dependen dalam penelitian ini disajikan tada tabel 5. 
ISSN : 2337-3067

E-Jurnal Ekonomi dan Bisnis Universitas Udayana 7.11 (2018): 2357-2388

Tabel 5. Hasil Evaluasi Validitas Model

\begin{tabular}{|c|l|l|c|c|}
\hline No & \multicolumn{1}{|c|}{$\begin{array}{c}\text { Variabel } \\
\text { Dependen }\end{array}$} & $\begin{array}{l}\text { Variabel } \\
\text { Independen }\end{array}$ & $\begin{array}{c}\text { Kemampuan } \\
\text { menjelaskan } \\
\text { Variabel Independen }\end{array}$ \\
\hline 1 & Jam Kerja (Y1) & $\begin{array}{l}\mathrm{X} 1, \mathrm{X} 2, \mathrm{X} 3, \\
\mathrm{X} 4, \mathrm{X} 5\end{array}$ & 0,907 & Kuat \\
\hline 2 & Pengeluaran (Y2) & $\begin{array}{l}\mathrm{X} 1, \mathrm{X} 2, \mathrm{X} 3, \\
\mathrm{X} 4, \mathrm{X} 5, \mathrm{Y} 1\end{array}$ & 0,948 & Kuat \\
\hline
\end{tabular}

Sumber:data diolah, 2017

Dalam pelelitian ini terdapat dua variabel dependen, yaitu jam kerja (Y1) dan pengeluaran rumah tangga (Y2). Terhadap kedua variabel dependen, variabel independen memberikan nilai Y1 memberikan nilai 0,907 sehingga variabel independen terhadap variabel dependen tergolong kuat. Sedangkan variabel tingkat pengeluaran rumah tangga (Y2) memberikan nilai 0,948 sehingga variabel independen terhadap variabel dependen tergolong kuat.

Koefisien determinasi total persamaan struktural dari model penelitian ini dengan perhitungan sebagai berikut :

$$
\begin{aligned}
& R_{m}^{2}=1-P_{e 1}^{2} P_{e 2}^{2} \ldots \ldots . P_{e p}^{2} \\
& R_{m}^{2}=1-(0,305)^{2}(0,228)^{2} \\
& R_{m}^{2}=1-(0,093)(0,052) \\
& R_{m}^{2}=1-0,005 \\
& R_{m}^{2}=0,99
\end{aligned}
$$

Koefisien determinan total sebesar 0,99 mempunyai arti bahwa sebesar 99 persen variabel dari pengeluaran rumah tangga dapat dijelaskan oleh model yang dibentuk, sedangkan sisanya sebesar 1 persen dijelaskan oleh variabel lain diluar model yang dibentuk. 
Wiji Rosiana, dan Ida Ayu Nyoman Saskara. Faktor-faktor yang menghambat..

\section{Pengaruh Langsung}

Untuk mengetahui pengaruh langsung antar variabel konstruk dapat dilihat dari hasil olahan data dengan nilai path coefficients yang ditampilkan pada tabel 6.

Tabel 6. Path Coefficient

\begin{tabular}{|c|c|c|c|l|}
\hline $\begin{array}{c}\text { Hubungan } \\
\text { Variabel }\end{array}$ & $\begin{array}{c}\text { Coefficient } \\
\text { Standar }\end{array}$ & $\begin{array}{c}\text { Standar } \\
\text { Error }\end{array}$ & P-value & Keterangan \\
\hline X1 -> Y1 & 0,157 & 0,667 & 0,019 & Signifikan \\
\hline X2 -> Y1 & 0,465 & 2,643 & 0,000 & Signifikan \\
\hline X3 -> Y1 & 0,393 & 3,196 & 0,001 & Signifikan \\
\hline X4 -> Y1 & $-0,151$ & 0,252 & 0,039 & Signifikan \\
\hline X5 -> Y1 & 0,060 & 1,962 & 0,422 & NonSignifikan \\
\hline X1 -> Y2 & $-0,048$ & 0,034 & 0,351 & NonSignifikan \\
\hline X2 -> Y2 & 0,380 & 0,144 & 0,000 & Signifikan \\
\hline X3 -> Y2 & 0,367 & 0,167 & 0,000 & Signifikan \\
\hline X4 -> Y2 & $-0,076$ & 0,013 & 0,179 & NonSignifikan \\
\hline X5 -> Y2 & 0,187 & 0,096 & 0,002 & Signifikan \\
\hline Y1 -> Y2 & 0,191 & 0,005 & 0,027 & Signifikan \\
\hline
\end{tabular}

Sumber :data diolah, 2017

Berdasarkan diatas menunjukkan bahwa secara individu variabel X1 (tingkat pendidikan) terhadap jam kerja memberikan nilai koefisien sebesar 0,157 dengan tingkat signifikansi sebesar 0,019 dibawah alpa 0,05. Variabel X1 (tingkat pendidikan) terhadap pengeluaran rumah tangga memberikan nilai koefisien sebesar -0,048 dengan tingkat signifikansi sebesar 0,351 diatas alpa 0,05. Hasil ini menunjukkan bahwa secara parsial variabel jam kerja tidak memediasi pengaruh variabel tingkat pendidikan terhadap pengeluaran rumah tangga pekerja wanita yang bekerja di industri laundry rumah tangga di Kecamatan Denpasar Selatan, hal ini berarti hipotesis yang diajukan ditolak. 
Variabel X2 (upah pekerja) terhadap jam kerja memberikan nilai koefisien sebesar 0,465 dengan tingkat signifikansi sebesar 0,000 dibawah alpa 0,05. Variabel X2 (upah pekerja) terhadap pengeluaran rumah tangga memberi nilai koefisien sebesar 0,380 dengan tingkat signifikansi sebesar 0,000 dibawah alpa 0,05. Kedua variabel ini dapat disimpulkan berpengaruh positif signifikan terhadap pengeluaran rumah tangga. Hasil penelitian ini menunjukkan bahwa secara parsial variabel jam kerja memediasi pengaruh variabel upah pekerja terhadap pengeluaraan rumah tangga wanita yang bekerja di industri laundry rumah tangga di Denpasar Selatan, hal ini berarti hipotesis yang diajukan diterima.

Variabel X3 (pendapatan suami) terhadap jam kerja memberikan nilai koefisien sebersar 0,393 dengan tingkat signifikansi sebesar 0,001 dibawah alpa 0,05. Variabel X3 (pendapatan suami) terhadap pengeluaran rumah tangga memberi nilai koefisien sebesar 0,367 dengan tingkat signifikansi 0,000 dibawah 0,05. Kedua variabel ini dapat disimpulkan berpengaruh positif signifikan terhadap pengeluaran rumah tangga. Hasil ini menunjukkan bahwa variabel jam kerja memediasi pengaruh variabel pendapatan suami terhadap pengeluaraan rumah tangga wanita yang bekerja di industri laundry rumah tangga di Kecamatan Denpasar Selatan, hal ini berarti hipotesis yang diajukan diterima.

Variabel X4 (umur) terhadap jam kerja memberikan nilai koefisien -0,151 dengan tingkat signifikansi sebesar 0,039 lebih kecil dari alpa 0,05. Variabel X4 (umur) terhadap pengeluaran rumah tangga memberikan nilai koefisien sebesar 0,076 dengan tingkat signifikansi sebesar 0,179 diatas alpa 0,05. Hasil ini 
Wiji Rosiana, dan Ida Ayu Nyoman Saskara. Faktor-faktor yang menghambat..

menunjukkan bahwa variabel jam kerja tidak memediasi pengaruh variabel umur terhadap pengeluaran rumah tangga pekerja wanita yang bekerja di industri laundry rumah tangga di Kecamatan Denpasar Selatan, hal ini berarti hipotesis yang diajukan ditolak.

Variabel X5 (jumlah tanggungan) terhadap jam kerja memberikan nilai koefisien sebesar 0,060 dengan tingkat signifikansi 0,422 lebih besar dari alpa 0,05. Variabel X5 (jumlah tanggungan) terhadap tingkat pendapatan menunjukkan nilai koefisien sebesar 0,187 dengan tingkat signifikansi 0,002 lebih kecil dari alpa 0,005. Hasil ini menunjukkan bahwa variabel jam kerja tidak memediasi pengaruh variabel jumlah tanggungan terhadap pengeluaran rumah tangga pekerja wanita yang bekerja di industri laundry rumah tangga di Kecamatan Denpasar Selatan, hal ini berarti hipotesis yang diajukan ditolak.

\section{Pengaruh Langsung, Pengaruh Tidak Langsung, Pengaruh Total}

Koefisien pada Tabel 7 merupakan koefisien jalur pengaruh langsung sedangkan ringkasan pengaruh langsung, tidak langsung, dan pengaruh total dapat dilihat pada Tabel 7 .

Tabel 7. Ringkasan Pengaruh Langsung, Pengaruh Tidak Langsung, Dan Pengaruh Total antar Variabel Penelitian

\begin{tabular}{|c|c|c|c|c|c|c|}
\hline \multirow{2}{*}{$\begin{array}{c}\text { Kontruk } \\
\text { Independen }\end{array}$} & \multicolumn{5}{|c|}{ Yonstruk Dependen } \\
\cline { 2 - 5 } & \multicolumn{3}{|c|}{} & \multicolumn{3}{c|}{ Y2 } \\
\cline { 2 - 5 } & PL & PTL & PT & PL & PTL & PT \\
\hline X1 & 0,157 & & 0,157 & $-0,048$ & $-0,009$ & $-0,057$ \\
\hline X2 & 0,465 & & 0,465 & 0,380 & 0,072 & 0,452 \\
\hline X3 & 0,393 & & 0,393 & 0,367 & 0,070 & 0,437 \\
\hline X4 & $-0,151$ & & $-0,151$ & $-0,076$ & $-0,001$ & $-0,077$ \\
\hline X5 & 0,060 & & 0,060 & 0,187 & 0,036 & 0,223 \\
\hline & & & & 0,191 & & \\
\hline
\end{tabular}

Sumber: data diolah, 2017 
Berdasarkan tabel diatas dijelaskan bahwa secara langsung variabel upah pekerja memiliki pengaruh dominan terhadap jam kerja dengan nilai sebesar 0,465 dan secara langsung variabel upah pekerja juga memiliki pengaruh paling dominan terhadap pengeluaran rumah tangga dengan nilai sebesar 0,380. Secara tidak langsung variabel upah pekerja melalui jam kerja memiliki pengaruh dominan terhadap pengeluaran rumah tangga dengan nilai sebesar 0,072 dan secara total nilai terbesar adalah variabel upah pekerja sebesar 0,452 .

\section{PEMBAHASAN}

Hasil analisis menunjukkan bahwa tingkat pendidikan berpengaruh positif signifikan terhadap jam kerja pekerja wanita, hal ini berarti hipotesis yang diajukan diterima. Hasil penelitian ini mendukung hasil penelitian Irto Sunardi (2017) yang berjudul Pengaruh Tingkat Upah Dan Tingkat Pendidikan Terhadap Jam Kerja Pekerja Wanita Pada Industri Perhotelan Di Kota Palembang, menyatakan bahwa adanya hubungan antara tingkat pendidikan dengan jam kerja rata-rata perkerja wanita. Pada tingkat pendidikan SMA/SMK jam kerja rata-rata pekerja wanita adalah 158,18 jam per bulan. Sedangkan pada tingkat pendidikan Diploma didapat bahwa jam kerja rata-rata perkerja wanita adalah 162 jam per bulan. Kemudian pada tingkat pendidikan sarjana, jam kerja rata-rata pekerja wanita adalah 175,76 jam per bulan. Dari hasil tersebut dikatakan bahwa tingkat pendidikan cenderung mempengaruhi jam kerja rata-rata pekerja wanita.

Mardalena (2010) didalam penelitiannya menyatakan bahwa, pendidikan akan memperbaiki status, kemampuan dan keahlian seorang wanita. Jika tingkat pendidikan wanita semakin tinggi, maka semakin efisien sistem yang diterapkan 
dalam rumah tangga. Dengan demikian akan semakin banyak waktu yang dapat dipergunakan secara produktif diluar pekerjaan rumah tangga. Sehingga dengan tingginya tingkat pendidikan seseorang, maka semakin mampu menagkap kesempatan ekonomi yang lebih baik di sekitarnya sekaligus meningkatkan mutu kerjanya.

Hasil analisis menunjukkan bahwa upah pekerja berpengaruh positif signifikan terhadap jam kerja pekerja wanita, hal ini berarti hipotesis yang diajukan diterima. Penelitian ini mendukung hasil penelitian Habibah dan Hendra (2014) yang berjudul Pengaruh Faktor Upah, Usia, Pendapatan Suami, Usia Anak Terakhir, Dan Pengeluaran Rumah Tangga Terhadap Curahan Jam Kerja Perempuan Menikah Di Kota Magelang, dari hasil uji statistik diketahui bahwa ada pengaruh signifikan dan positif antara upah terhadap curahan jam kerja. Penelitian ini memperoleh hasil perhitungan statistik t hitung $=3,743$. Dengan menggunakan $\alpha=0,05$ diperoleh nilai $\mathrm{t}$ tabel sebesar 1,664. Maka t hitung $(3,743)$ $>\mathrm{t}$ tabel $(1,664)$. Sehingga dapat disimpulkan bahwa ada pengaruh signifikan dan positif variabel upah terhadap curahan jam kerja perempuan menikah. Semakin besar jam kerja yang dicurahkan maka upah yang diperoleh semakin meningkat, ditambah pekerja juga bisa mecurahkan waktunya diluar jam kerja yaitu lembur (over time). Semakin besar waktu lembur yang di curahkan maka upah yang diperoleh semakin meningkat (Eliana dan Ratina, 2007).

Selanjutnya hasil analisis menunjukkan bahwa pendapatan suami berpengaruh positif signifikan terhadap jam kerja pekerja wanita, hal ini berarti hipotesis yang di ajukan diterima. Penelitian ini mendukung hasil penelitian dari Soeberano 
(2014) yang menyatakan dalam penelitiannya yang berjudul analisis FaktorFaktor Yang Memperngaruhi Jam Kerja Pedagang Sayur Wanita Di Kecamatan Ambulu Kabupaten Jember, bahwa variabel pendapatan pendapatan suami (X2) meningkatkan curahan jam kerja sebesar 0,461 jam per hari. Pendapatan suami merupakan jumlah upah yang diperoleh suami, yang digunakan untuk memenuhi kebutuhan rumah tangga. Semakin tinggi pendapatan suami maka tingkat curahan jam kerja pekerja wanita akan semakin meningkat. Curahan jam kerja akan semakin meningkat pada wanita yang bekerja di sektor industri rumah tangga, selain bekerja perempuan dapat membantu perekonomian rumah tangga. Peranan wanita pekerja memperlihatkan bahwa disamping urusan rumah tangga seperti mengasuh anak, memasak, dan lain-lain, juga mampu menghasilkan uangdan memberikan kontribusi bagi pendapatan keluarga.

Hasil analisis menunjukkan bahwa umur berpengaruh negatif signifikan terhadap jam kerja pekerja wanita, hal ini berarti hipotesis yang di ajukan ditolak. Hasil penelitian ini mendukung penelitian Berliana dan Purbasari (2016) yang berjudul Faktor-Faktor Yang Mempengaruhi Jam Kerja Tenaga Wanita Berstatus Kawin Dalam Seminggu Di Indonesia menyatakan bahwa umur berpengaruh negatif terhadap jam kerja, hal ini menunjukkan bahwa wanita kawin yang berusia lebih tua mempunyai kecenderungan yang lebih kecil untuk bekerja lebih dari 40 jam dalam seminggu. Nilai oods ratio sebesar 0,986, artinya setiap kenaikan satu tahun usia wanita kawin akan menurunkan kecenderungan wanita kawin bekerja lebih dari 40 jam dalam seminggu. 
Wiji Rosiana, dan Ida Ayu Nyoman Saskara. Faktor-faktor yang menghambat..

Selanjutnya hasil analisis menunjukkan bahwa jumlah tanggungan berpengaruh positif tidak signifikan terhadap jam kerja pekerja wanita, hal ini berarti hipotesis yang di ajukan ditolak. Hasil penelitian ini mendukung hasil penelitian dari Olga (2016) yang berjudul analisis Faktor-Faktor Yang Mempengaruhi Curahan Waktu Kerja Wanita Di Desa Banjaragung Kabupaten Jombang Pada Industri Sepatu Sebagai Bentuk Kontribusi Terhadap Ekonomi Keluarga, menyatakan bahwa variabel jumlah tanggungan keluarga memiliki nilai koefisien sebesar 0,3053 dimana 0,3053>0,05, selain itu nilai t-statistiknya juga kurang dari nilai t-tabel $(1,034758>1,67303)$. Hipotesis yang diterima adalah H0 dan menolak H1 yaitu variabel bebas tidak berpengaruh secara nyata terhadap variabel terikat atau jumlah tanggungan keluarga tidak berpengaruh secara nyata terhadap curahan waktu kerja wanita. Dengan demikian apabila jumlah tanggungan keluarga bertambah, tenaga kerja wanita tidak akan menambah jam kerja karena mereka menggunakan waktu lainnya untuk mengurus keluarga.

\section{Pengaruh Tingkat Pendidikan, Upah Pekerja, Pendapatan Suami, Umur, Jumlah Tanggungan Terhadap Pengeluaran Rumah Tangga.}

Hasil analisis menunjukkan bahwa tingkat pendidikan berpengaruh negatif tidak signifikan terhadap pengeluaran rumah tangga pekerja wanita, hal ini berarti hipotesis yang diajukan ditolak. Dengan demikian penelitian ini mendukung hasil penelitian Buhang (2015) yang berjudul Analisis Konsumsi Rumah Tangga di Kecamatan Batui Kabupaten Banggai, yang menyatakan hasil uji statistik memperlihatkan bahwa nilai koefisien regresi pendidikan adalah sebesar $-0,015$. Hal ini berarti bahwa setiap tingkat pendidikan bertambah 1 (satu) tahun dengan asumsi variabel lain tetap, maka akan mengurangi ratio konsumsi sebesar 0,015 
persen. Hal ini diketahui dengan melihat tingkat signifikansi yang mana dilihat dari nilai probabilitasnya sebesar 0,254 . Nilai tersebut berada diatas batas toleransi yaitu 0,05. Dengan demikian dikatakan bahwa pendidikan tidak berpengaruh secara signifikan terhadap konsumsi pada rumah tangga di Kecamatan Batui.

Selanjutnya hasil analisis menunjukkan bahwa upah pekerja berpengaruh positif signifikan terhadap pengeluaran rumah tangga pekerja wanita, hal ini berarti hipotesis yang diajukan diterima. Penelitian ini mendukung hasil penelitian Danil (2013) yang berjudul Pengaruh Pendapatan Terhadap Tingkat Konsumsi pada Pegawai Negeri Sipil di Kantor Bupati Kabupaten Bireun, yang menyatakan bahwa sebesar 89,4\% kontribusi tinggirendahnya pendapatan Pegawai Negeri Sipilpada tingkat konsumsi. Dengan demikian jelaslah bahwa pendapatan seseorang atau rumah tangga sangat berhubungan dengan tingkat konsumsi. Karena semakin tingginya pendapatan maka semakin baiknya mempengaruhi konsumsi seseorang. Semakin besar pendapatan yang diperoleh maka pengeluaran untuk konsumsi makin besar pula.

Hasil analisis menunjukkan bahwa pendapatan suami berpengaruh positif signifikan terhadap pengeluaran rumah tangga pekerja wanita, hal ini berarti hipotesis yang di ajukan diterima. Penelitian ini mendukung hasil penelitian Anastia (2014) yang berjudul Kontribusi Pendapatan Pedagang Buah Terhadap Pengeluaran Rumah Tangga, yang menyatakan bahwa pendapatan suami (X2) memiliki nilai t-hitung $(3,610)>$ nilai t-tabel $(1,671)$ maka H0 di tolak, ini berarti pendapatan suami (X2) berpengaruh positif dan signifikan terhadap pengeluaran 
rumah tangga. Artinya pendapatan suami akan meningkat sebesar 1 rupiah maka pengeluaran rumah tangga akan meningkat sebesar 0,314 rupiah dengan asumsi kedua variabel bebas bernilai konstan. Hal ini di perkuat dengan penelitian Nurul (2006) bahwa pendapatan suami berpengaruh positif dan signifikan terhadap pengeluaran rumah tangga, pendapatan suami yang relatif besar akan memenuhi kebutuhan rumah tangganya.

Hasil analisis menunjukkan bahwa umur berpengaruh negatif tidak signifikan terhadap pengeluaran rumah tangga pekerja wanita, hal ini berarti hipotesis yang diajukan ditolak. Hasil penelitian ini mendukung penelitian dari Dianawati dan Mustika (2016) yang berjudul Analisis Pengaruh Pengeluaran Konsumsi Pedagang Canang Di Pasar Tradisional Kecamatan Denpasar Barat, yang menyatakanbahwa koefisien regresi dari umur yaitu 0,022 berarti apabila umur bertambah satu tahun dengan anggapan variabel bebas lainnya konstan, maka pengeluaran konsumsi pedagang canang akan naik Rp 22.000,-. Dilihat dengan tidak tingginya jumlah pengeluaran konsumsi dikarenakan umur seorang pedagang bukan jaminan berkurangnya stamina seseorang dalam bekerja sehingga umur bukanlah menjadi acuan seorang pedagang canang dalam beraktivitas, hal ini dikarenakan bahwa besar kecilnya umur pedagang bukan menjadi alasan utama dalam menentukan pengeluaran konsumsi rumah tangganya. Dengan demikian variabel umur tidak memberikan dampak yang signifikan terhadap pengeluaran konsumsi pedagang canang.

Dilihat dari hubungan jumlah tanggungan terhadap pengeluaran rumah tangga, hasil analisis menunjukkan bahwa jumlah tanggungan berpengaruh positif 
signifikan terhadap pengeluaran rumah tangga pekerja wanita, hal ini berarti hipotesis yang diajukan diterima. Hasil penelitian ini mendukung peneltian dari Dianawati dan Mustika (2016) yang berjudul Analisis Pengaruh Pengeluaran Konsumsi Pedagang Canang Di Pasar Tradisional Kecamatan Denpasar Barat, yang menyatakan bahwa koefisien regresi dari jumlah tanggungan sebesar 0,688 berarti bahwa apabila jumlah tanggungan bertambah 1 orang dengan anggapan variabel bebas lainnya konstan, maka pengeluaran konsumsi pedagang canang akan naik Rp 688.000,-. Menurut Nababan (2013), dimana dalam penelitiannya menyatakan bahwa variabel jumlah tanggungan berpengaruh positif terhadap pola konsumsi PNS Dosen dan Tenaga Kependidikan pada Fakultas Ekonomi dan Bisnis Unversitas Sam Ratulangi Manado. Berdasarkan hasil analisis tersebut, dapat dijelaskan bahwa semakin banyak jumlah tanggungan mampu menambah jumlah pengeluaran konsumsi.

\section{SIMPULAN DAN SARAN}

Tingkat pendidikan, upah pekerja dan pendapatan suami berpengaruh positif signifikan terhadap jam kerja pekerja wanita yang bekerja di industri laundry rumah tangga di Kecamatan Denpasar Selatan. Umur berpengaruh negatif signifikan terhadap jam kerja pekerja wanita. Jumlah tanggungan keluarga berpengaruh positif tidak signifikan terhadap jam kerja pekerja wanita. Upah pekerja, pendapatan suami, jumlah tanggungan keluarga dan jam kerja berpengaruh positif signifikan terhadap pengeluaran rumah tangga pekerja wanita. Tingkat pendidikan dan umur berpengaruh negatif tidak signifikan terhadap pengeluaran rumah tangga pekerja wanita. Jam kerja memediasi pengaruh tingkat 
Wiji Rosiana, dan Ida Ayu Nyoman Saskara. Faktor-faktor yang menghambat..

pendidikan, upah pekerja, pendapatan suami dan umur terhadap pengeluaran rumah tangga pekerja wanita. Sedangkan jam kerja tidak memediasi pengaruh jumlah tanggungan keluarga terhadap pengeluaran rumah tangga pekerja wanita yang bekerja di industri laundry rumah tangga di Kecamatan Denpasar Selatan.

Pemerintah Kota Denpasar melakukan upaya untuk meningkatkan kesejahteraan masyarakat dengan cara memberikan pelatihan khususnya kepada wanita yang bekerja di industri laundry rumah tangga, agar mereka mampu mengeksplor kemampuannya untuk meningkatkan kebutuhan ekonomi rumah tangga. Pelatihan tersebut meliputi tentang bagaimana cara karyawan laundry memberikan pelayanan terhadap pelanggan laundry dengan baik dan benar, sehingga pelanggan merasa puas dengan pelayanan yang diberikan oleh karyawan laundry. Teknis dalam bekerja agar lebih baik, sehingga kualitas dari hasil pakaian yang telah di cuci menjadi lebih baik. Pekerja wanita harus pintar membagi waktu antara waktu bekerja di laundry dengan waktu bekerja di rumah sebagai ibu rumah tangga, sehingga pekerjaan di laundry tidak mengganggu pekerjaan rumah tangga pekerja wanita yang harus diselesesaikan sebagaimana mestinya. Karena didalam penelitian ini pekerja wanita memiliki peran ganda yaitu sebagai karyawan laundry dan sebagai ibu rumah tangga. Pemilik usaha perlu memperhatikan fasilitas di tempat kerja demi kenyamanan karyawan atau pegawai sehingga dapat mengurangi dampak negatif dari jam kerja yang panjang seperti kelelahan, stres dan jenuh.

\section{REFERENSI}


Anastia, Petika dan Made Sukarsa. 2014. Kontribusi Pendapatan Pedagang Buah Terhadap Pengeluaran Rumah Tangga (Studi Kasus: Pedagang Buah di Pasar Badung Kota Denpasar). E-Jurnal EP Unud, 3[7] :301 - 310.

Badan Pusat Statistik Kota Denpasar. 2016. Statistik Daerah Kecamatan Denpasar Selatan 2016. Badan Pusat Statistik Kota Denpasar

Berliana, Sarni Maniar dan Lukmi Ana Purbasari. 2016. Faktor-faktor yang mempengaruhi Jam Kerja Tenaga Kerja Wanita berstatus kawin dalam seminggu di Indonesia. Jurnal Ilmiah Widya. Vol 3 No 4.

Buhang, Amir, 2015. Analisis Konsumsi Rumah Tangga Di Kecamatan Batui Kabupaten Banggai. Jurnal Dosen Universitas Tompotika Luwuk Banggai. JAM No. 2 Vol. 9.

Case, Karl E dan Ray C. Fir. 2002. Prinsip-PrinsipEkonomi Makro, Edisi Kelima. PT. Prenhallindo, Anggota IKAPI. Jakarta.

Chandrasekhar S, Mousumi Das dan Ajay Sharma. 2014. Short-term Migration and Consumption Expenditure of Household in Rural India. Journal Oxford Development Studies. Vol. 43, No. 1, 105-122.

Danil, Mahyu, 2013. Pengaruh Pendapatan Terhadap Tingkat Konsumsi Pada Pegawai Negeri Sipil Di Kantor Bupati Kabupaten Bireuen. Jurnal ekonomika Universitas Almuslim Bireuen - Aceh Vol. IV No.7

Dianawati, Weni dan Made Dwi Setyadhi Mustika, 2016. Analisis Pengaruh Pengeluaran Konsumsi Pedagang Canang Di Pasar Tradisional Kecamatan Denpasar Barat.E-Jurnal EP Unud, 5 [5] : 530-556

Dinas Koperasi Usaha Kecil Menegah Kota Denpasar. 2016. Jumlah Usaha Laundry di Kota Denpasar.

Dwi, Setyadi Mustika Made dan Putu Desy Apriliani. 2013. Analisis FaktorFaktor yang Mempengaruhi Kebertahanan Pedagang Kuliner Tradisional di Kabupaten Klungkung. Jurnal Ekonomi Kuantitatif Terapan Vol. 6 No. 2

Erwin Adiana, Pande Putu dan Ni Luh Karmini. 2012. Pengaruh Pendapatan, Jumlah Anggota Keluarga Dan Pendidikan Terhadap Pola Konsumsi 
Wiji Rosiana, dan Ida Ayu Nyoman Saskara. Faktor-faktor yang menghambat..

Rumah Tangga Miskin Di Kecamatan Gianyar. E-Jurnal EP Unud, 5[6] : $39-48$

Espinal, Rosario \& Sherri Grasmuck. 1997. Gender, Households and Informal Enterpreneurship in The Dominica Republik. Jurnal of Comparative Family Studies.28(1). P:103-128.

Handoko, Haryo Bagus. 2009. Sukses Wirausaha Laundry di Rumah. PT. Gramedia Pustaka Utama: Jakarta

Hyman, Eric L. 2012. The Role Of Small and Micro Enterprices in Regional Development. Bulletin of Indonesian Economics Studies. 4(4): pp: 197214.

Kaufman, Bruce E. dan Julie L. Hotchkiss, 2000. The Economics of Labor Markets. Orlando: The Dryden Press.

Kurniawan, Jarot. 2016. Dilemma Pendidikan dan Pendapatan di Kabupaten Grobogan. Jurnal Ekonomi Kuantitatif Terapan, [S.1.], Juli 2016.ISSN 2303-0186.

Larsson K. Hedenstöm H. and Malmberg P. 1987. Learning Effects, Variation during Office Hours and Reproducibility of Static and Dynamic Spirometry. International Jurnal of Thoracic Medicine, 51(3):h:74-88.

Mardalena, Ervin. 2010. Faktor-faktor yang berpengaruh terhadap Penawaran Tenaga Kerja Wanita di Sumatra Selatan. Jurnal Ekonomika. Vol II No. 1 April 2010. Hal 51-65

Massey, D.S, J. Arango, G. Hugo, A. Kouaouci, A. Pelpegrino, and J. E. Taylor. (1993). Theories of International Migration: A Review and Appraisal. Population and Development Review, Vol. 19, No. 3, (Sep. 1993), pp. 431-466

Nababan, Septia. 2013. Pendapatan dan Jumlah Tanggungan Pengaruhnya Terhadap Pola Konsumsi PNS Dosen dan tenaga Kependidikan Pada Fakultas Ekonomi dan Bisnis Universitas Sam Ratulangi Manado. Jurnal EMBA Vol.1 No.4 Desember 2013, Hal. 2130-2141.

Neves, David \& Du Toit. 2012. Money and Sociality In South Africa's Informal Economy. Jurnal International African Institute 2012, 82(1): p:131-149. 
Nurul, Hidayah. 2006. Profil Wanita Pedagang Sayur Mayur dan Kontribusi Terhadap Pendapatan Rumah Tangga (Studi kasus di Pasar Tanjung Anyar Kec. Magersari Kab. Mojokerto). Skirpsi Fakultas Ekonomi Universitas Muhammadiyah Malang.

Olga, Claudia Gusti Wanda. 2016. Analisis Faktor-Faktor yang Mempengaruhi Curahan Waktu Kerja Wanita di Desa Banjaragung Kabupaten Jombang pada Industri Sepatu Sebagai Bentuk Kontribusi Terhadap Ekonomi Keluarga. Jurnal Ilmiah Jurusan Ilmu Ekonomi Fakultas Ekonomi dan Bisnis Universitas Brawijaya.

Parinduri, Rasyad A. 2016. Family Hardship and The Growth of Micro and Small Firms in Indonesia. Bulletin of Indonesian Economic Studies. 50(1), pp: 53-73.

Paula, Broght. 2002. Women Work and Welt-Being: The Influence of Work Family and Family-Work Confliet. New Zaeland Journal of Psychology. Vol. 31, No. 1 June 2002.

Pratomo, Devanto Shasta. 2017. Pendidikan dan Partisipasi Angkatan Kerja Wanita di Indonesia. Jurnal Ekonomi Kuantitatif Terapan Vol. 10 No.2

Putri, Nadia Maharani dan Evi Yulia Purwanti.2012. Analisis Penawaran Tenaga Kerja Wanita Menikah dan Faktor yang Mempengaruhinya di Kabupaten Brebes. Diponegoro Jurnal Of Economics. Vol. 1. No. 1 Tahun 2012 HIm. 1-13.

Raharja, Pratama dan Mandala Manurung. 2005. Teori Ekonomi Makro. Jakarta.

Rahayu, Shabrina Umi dan Ni Made Tisnawati.2014.Analisis Pendapatan Keluarga Wanita Single Parent (Studi Kasus Kelurahan Sesetan, Kecamatan Denpasar Selatan, Kota Denpasar). Jurnal Ekonomi Kuantitatif Terapan. Vol 7 (2): 83-89.

Rosediana, Eka Sulistyani. 2016. Pengaruh Pendapatan, Usia, Jumlah anggota Keluarga dan Jenis Kelamin Terhadap Konsumsi Buruh Garmen di Kabupaten Semarang. Eprints Undip, 18. 
Wiji Rosiana, dan Ida Ayu Nyoman Saskara. Faktor-faktor yang menghambat..

Saskara, Ida Ayu Nyoman dan A.A.I.N Marhaeni. 2017. The Role of Social Capital and Business of Banten to Increase Balinese Women's Employment. Journal of Comparative Asian Development. ISSN 15339114 (print) 2150-5403 (Online). Vol 16:1, 68-86. DOI $10.1080 / 15339114.2017 .1292930$

Saskara, Ida Ayu Nyoman, Pudjiharjo, Ghozali Maskie dan Agus Suman. 2012. Jurnal Aplikasi Manajemen. Volume 10, Nomor 3.

Scholten, Elisabeth Locher. 1987. Female Labour in Twentieth Century Java, European Nations-Indonesia Practice, dalam Scholten dan Nihof (ed). Indonesian Women Focus. USA: Foris Publication.

Soberano, Tamio et al. 2014. Analisis Faktor-Faktor Yang Mempengaruhi Jam Kerja Pedagang Sayur Wanita Di Kecamatan Ambulu Kabupaten Jember. Jurnal EP Fakultas Ekonomi Universitas Jember.

Sumarwan. 1993. Keluarga Masa Depan dan Perubahan Pola Konsumsi. Warta Demografi. Jakarta.

Sunardi, Irto. 2017. Pengaruh Tingkat Upah Dan Tingkat Pendidikan Terhadap Jam Kerja Pekerja Wanita Pada Industri Perhotelan Di Kota Palembang.

Suyana Utama Made, 2010. Modul Metode Kuantitatif. Diktat Kuliah Magister Ilmu Ekonomi Universitas Udayana.

Ware, Helen. 1981. Women, Demography and Development. Development Studies Centre Series: Demography Teaching Notes, Canberra: Australia Nasional University 